\title{
Dependency, White Privilege, and Transnational Hegemonic Reconfiguration: Investigating Systems of Power and Identity Privilege in The Bahamas
}

David Allens

White cultural hegemony has been used as a determinant of identity privilege in The Bahamas since the beginning of British colonialism. This ideal justifies and confers the dominance of whiteness while also including a moral responsibility to enforce the racial hierarchy as a part of a "global cognitive dysfunction" (Mills 18) that sees non-white actors as intrinsically lesser; an understanding Charles Mills argues is needed to uphold a racialized social contract. This "grammar of racial difference" inculcates the need for whiteness to act as savior through the subjugation and cultural integration of the "other" (Mahmud).

However, beyond its role as a dysfunction, this conception of a moral obligation-or colloquially, a 'white savior complex'-guides understandings of why colonial leaders forged hegemonic relationships with the U.S. despite the country's apparent intent to achieve independence. These relationships were a strategic part of a colonial-savior complex and adherence to a global system that values 'whiteness.'

As The Bahamas neared independence in 1973, the actions of its white-majority internal self-governance began reconfiguring the existing colonial regime of identity privilege. Competing in a racially-constructed global capitalist environment requires forging strategic economic ties and trade agreements with world superpowers such as the United States' while adhering to international regulations. Inadvertently, imperialist and hegemonic relationships are created.

This essay discusses how racial capitalism and Mills' global system of white supremacy is demonstrated through economic reliance on the U.S. and global systems, and how Mills' conception explains the construction of identity privilege based on global imperialism in the context of American hegemonic influence. This essay will track the construction of identity privilege for the normative Westerner (including North American) in The Bahamas that is developed from normative whiteness and the factors that facilitate the continuation of the current state.

\section{Historical Construction of White Identity Privilege in The Bahamas}

As an archipelago 50 miles off the coast of South Florida, historical connections through geographical proximity are frequent. These connections include rum-running, bootlegging, and the later tourism boom of the 1920s, as well as a short-lived occupation by U.S. marines seeking supplies during the American War of Independence.

However, these connections often come as a double-edged sword. For example, the tourism boom in the 1920s saw the development of the industry and boosts to the economy but worsened the racial situation and hardened the existing color line with importations of Jim Crow understandings to The Bahamas in creating environments both comfortable and socially familiar for white tourists (Saunders). 
The United States has always been an important trade partner for imports, even before independence, due to the country's distance from Britain. The Bahamas currently imports nearly all its food and manufactured goods from the United States (U.S. Department of State, n.d.). As a result, the idea of a normative American and Westerner has been attached to that of prosperity.

The application of independence was intended to provide freedom from colonialism. However, one might contend that it has not proved as advantageous as hoped due to the Western hegemonic forces inculcated in Bahamian society. Forces like racialized post-colonial U.S. cultural imperialism and multi-national imposition were introduced and facilitated by geographical proximity, by socio-economic elites welcoming racialized Western forces as a trade-off for solidifying and maintaining power, and by political influence of global hegemonic forces over the nation's elite.

\section{Reconfiguration Through Liberalism and Transnational Supports}

Multiple historical processes have constituted, transformed, and perpetuated regimes of privilege in The Bahamas. The Racial Contract requires its signatories to subscribe to misunderstandings about the world under the assurance that these conceptions will be validated by a universal "white epistemic authority". According to Mills (19), unlike an ideal social contract, these prescribed misunderstandings (or "localized and global cognitive dysfunctions") require their own prescribed "schedule of structural blindness and opacities" to maintain white supremacist order. One such misconception is derived from colonial ontology, which perpetuates the view that ideas, thoughts, and behaviors must be imported from the more civilized and advanced "mother" country. While this explains what occurs in a strictly colonial environment, this complex idea transforms into a post-colonial presentation that maintains a global system of white supremacy and liberty as its legitimizing ideology. For Mahmud (1999), in a colonial environment, Europe forms the consolidation of History, and the Other is then forced always to compare itself to those standards. Perhaps then, in a post-colonial, imperialist environment, this understanding is expanded from Europe to the West.

The colonial argument is that History, as it occurs in Europe, is what will eventually occur outside of it (Mahmud). If this is expanded from Europe to the West, then pressures from first-world countries and multi-national agencies occur under this racialized idea of fixing the "other." Essentially, the "West" expects its liberal values and way of life to spread to the rest of the world because of its intrinsic superiority. Moreover, liberalism itself contends that further development requires open multinational connections. To achieve this development, the global system of white supremacy and racial capitalism is enforced either through complacency or imposition.

According to the Inter-American Development Bank (IDB) Wages and Productivity Survey, tourism and tourism-related activity account for $60 \%$ of The Bahamas' GDP, directly or indirectly employing about $50 \%$ of the workforce, while financial services account for $15 \%$ of the GDP. Using the example of these core Bahamian industries (banking and tourism), it is interesting to consider the competing axes of the complicit position of local elites (in the case of racialized U.S. cultural hegemony as a facet of global imperialism) and the more overt regulatory-sanction methods (used by multi-national organizations in banking and related economic fields) that allowed the construction or reconfiguration of identity privilege. 
These axes are both essential factors in perpetuating white supremacy; however, it is often a challenging distinction to make. For example, in the case of racialized U.S. cultural imperialism, it has been an implicit and gradual process, not one as a result of any definite U.S. imposition. Comparatively, multi-national regulation upholding tenents of racial capitalism is overt and sanctions resulting from a breach of them is swift and severe.

\section{U.S. Cultural Imperialism}

The interrelationship between The Bahamas and America's political, economic, and social practices, and their geographies is a complex one. U.S. tourists constitute the majority of visitors to the country, at 6.6million a y (The Nassau Guardian). They also account for large amounts of Foreign Direct Investment (FDI). Moreover, due to The Bahamas' dependence on tourism and trade (mainly from the United States), the economy is often affected by U.S. economic performance.

One key example of American FDI demonstrates the transition from the British colonial regime of white supremacy to a regime of U.S. hegemony rooted in white supremacy but not enforced through direct rule. In 1955, the colonial, white Bahamian government signed the Hawksbill Creek Agreement, which granted sweeping tax exemptions to American lumber financier Wallace Groves and his newly created Grand Bahama Port Authority Limited. It also provided exemption from regulatory control and a crown grant of 51,000 acres to administer a port area for 99 years (EncylopaediaBritannica, n.d.). Over time, amendments have revised the prerogatives; however, the agreement has mostly remained the same. This arrangement served as a pivot point for the reconstruction of identity privilege, as the creation of a "free port" was meant to whet The Bahamas' appetite for more American industrial and tourism investment, which would feed a normative definition of whiteness. Today, those with FDI can apply for Permanent Residency when they invest in a residence valued at $\$ 750,000$, and for accelerated consideration for a residence valued at $\$ 1,500,000$ or more (Daminos Realty).

Similarly, the 1963 transfer of authority from the colonial government to the U.S. through a joint agreement to facilitate the opening of the United States' Atlantic Undersea Test and Evaluation Center (AUTEC) marks a shift in political influence. The agreement allowed the U.S. government to establish a naval base on the eastern coast of Andros Island with easy access to the "Tongue of the Ocean" for testing.

U.S. hegemonic force would continue to assert its political influence. In response to charges that it was not actively working to reduce drug trafficking, the Bahamian government allowed U.S. Customs Service to operate the first Tethered Aerostat Radar System out of High Rock, Grand Bahama, in 1984.

\section{Pressure from International Regulations and Agencies}

In addition to accounting for between 15-20\% gross domestic product (GDP), the Bahamian financial services industry forms the backbone of the middle class, with its human capital being predominately Bahamian (The Bahamas Investor) As a result, governance bodies hold much influence over The Bahamas.

The leverage held by standards agencies and international organizations can be gleaned from a statement in S\&P's Global Rating of The Bahamas threatening severe penalties. The American-based credit rating said that it "could lower [its] rating... over this period," in the 
event that the government did not institute measures to improve public finances as quickly as expected. Additionally, it warned that a "lack of confidence" over increasing debt costs would result in a downgrade. Conversely, the document explained that a reduction to the increase in government debt "beyond [their] expectations" could lead to an upgrade (S\&P Global Ratings).

Lending agencies like the International Monetary Fund (IMF) and the Inter-American Development Bank (IDB); organizations like the Financial Action Task Force (FATF), the Organization for Economic Co-Operation and Development (UECD); and frameworks like the U.S. Foreign Accounting Tax and Compliance Act (FATCA) and Common Reporting Standard (CRS) force countries and industries to change processes quickly and according to their varying desires. Pressure from these global organizations results in the enforcement of racial capitalism and a global white supremacist regime.

While, for Melamed, contemporary liberal and multicultural terms place a value on forms of humanity to align with "state-capital orders," (77) perhaps in a global conception, they align with supranational-capital orders. In line with these orders, multi-national organizations may be seen as coercing developing countries into loan capacities while forcing additional restrictions when arbitrary debt-service ratios are not met.

These international organizations may then maintain leverage over 'non-nations' through their control of intermediary banking systems (including American banks like JP Morgan Chase), which patrol access to international markets and regularly threaten with blacklisting.

This may be seen as the remnants of the bases of the "modern grammar of racial difference" (Mahmud). While an argument may be made for the technical competencies of these organizations, they may be perceived as an actualization of a European understanding of a duty to govern those below them in the racial hierarchy with the goal of seeing them achieve reason, the rule of law, and an ideal level of "prosperity" - what Fanon might argue to be demonstrative of a European authority complex.

\section{Conclusion}

It may be argued that the identity privilege outlined, which posits an ideal of "Western-ness" (i.e., enforced international alignment and perceived coerced cultural imperialism) at its apex, represents reliance on phenotypical and normative definitions of "whiteness"' While these processes are generally controlled by those who are phenotypically white, one might suggest that their normative 'whiteness' is the source of privilege. The hegemonic relationships resulting from either imposition or complacency form a normative definition of whiteness and identity privilege in a Bahamian context that aligns with an image of expatriates, foreign investment, and conspicuous consumption.

Much like import rates, examples of how this identity privilege has been entrenched is demonstrated through how market forces react to primarily American, Western programming. With privatized T.V. provider services, subscriptions to television streams are based on public desire. It is interesting then to note that options for station subscriptions remain largely along normative American categories (Cable Bahamas).

The cultural hegemony of the United States as an industrialized giant merely filled the void that British rule left behind. Mannoni might argue that this is representative of "a need for dependency." However, a more critical analysis might also contend that any need for 
dependency is a learnt one as a result of colonization. Fanon posits that it is "the racist who creates his inferior." With this in mind, we could consider Mannoni's "dependency complex" as one that exists only as a result of the sense of inferiority created by the racist and privileged. As a result, a learnt dependency on colonial leadership is replaced by racialized U.S. cultural imperialism and enforced global imperialism via multi-national organizations.

This paper suggests that despite independence, The Bahamas remains subjected to the dependent role under a system of white privilege resulting from colonial agreements made with the United States, multi-national agencies, and regulatory bodies that enforce a hegemonic reconstruction of influence. 


\section{Works Cited}

Cable Bahamas. "Channel Lineup." REV, https://www.cablebahamas.com/revtv/comparechannels/. Accessed 14 Oct. 2019.

Daminos Realty. “Acquiring Bahamian Permanent Residency By Investment.” Bahamas Real Estate Blog, 22 May 2018, https://www.sirbahamas.com/bahamasrealestateblog/acquiring-bahamian-permanentresidency-by-investment/.

EncylopaediaBritannica. "Freeport | The Bahamas |." Britannica.Com, https://www.britannica.com/place/Freeport-The-Bahamas\#ref266376. Accessed 14 Oct. 2019.

Fanon, Frantz. Black Skin, White Masks. Grove Press, 2008.

Mahmud, Taayab. "Colonialism and Modern Constructions of Race: A Preliminary Inquiry." University of Miami Law Review, vol. 53, July 1999, https://getit.library.utoronto.ca/index.php/oneclick?ctx_ver=Z39.882004\&ctx_enc=info\%3Aofi\%2Fenc\%3AUTF8\&rfr_id=info\%3Asid\%2Fsummon.serialssolutions.com\&rft_val_fmt=info\%3Aofi $\% 2 \mathrm{Ff}$ $\mathrm{mt} \% 3 \mathrm{Akev} \% 3 \mathrm{Amtx} \% 3 \mathrm{Ajournal} \& \mathrm{rft} . \mathrm{genre}=$ article $\& \mathrm{rft}$.atitle=Colonialism+and+modern + constructions+of + race $\% 3 \mathrm{~A}+\mathrm{a}+$ preliminary+inquiry \& rft.jtitle $=$ University + of $+\mathrm{Miami}+\mathrm{La}$ $\mathrm{w}+$ Review\&rft.au=Mahmud\%2C+Tayyab\&rft.date=1999-07$01 \&$ rft.pub=University+of + Miami\&rft.issn $=0041-$ 9818\&rft.volume $=53 \&$ rft.issue $=4 \&$ rft.spage $=1219 \&$ rft.externalDBID $=$ BSHEE \&rft.exter nalDocID=A58919158.

Melamed, Jodi. "Racial Capitalism." Critical Ethnic Studies, vol. 1, no. 1, 2015, pp. 76-85. JSTOR, doi:10.5749/jcritethnstud.1.1.0076.

Mills, Charles W. Racial Contract. Cornell University Press, 1999. ProQuest Ebook Central, http://ebookcentral.proquest.com/lib/utoronto/detail.action?docID=3138625.

Saunders, Gail. Race and Class in The Colonial Bahamas, 1880-1960. University Press of Florida, 2016.

S\&P Global Ratings. RatingsDirect: The Commonwealth of The Bahamas. 18 Dec. 2018, p. 9.

The Bahamas Investor. Roadmap for Financial Services. 2017, http://www.thebahamasinvestor.com/2017/roadmap-for-financial-services/.

The Nassau Guardian. "Historic Tourist Arrivals in 2018." The Nassau Guardian, 21 Mar. 2019, https://thenassauguardian.com/2019/03/21/historic-tourist-arrivals-in-2018/.

U.S. Department of State. "U.S. Relations With the Bahamas." United States Department of State, https://www.state.gov/u-s-relations-with-the-bahamas/. Accessed 14 Oct. 2019. 